\title{
Title
}

\section{Physiological (TCR-like) regulated lentiviral vectors for the generation of improved CAR-T cells}

María Tristán-Manzano ${ }^{1 *}$, Noelia Maldonado-Pérez ${ }^{1 *}$, Pedro Justicia-Lirio ${ }^{1,2}$, Pilar Muñoz ${ }^{1}$, Marina Cortijo-Gutiérrez ${ }^{1}$, Kristina Pavlovic ${ }^{1,3}$, Rosario Jiménez-Moreno ${ }^{3}$, Sonia Nogueras ${ }^{3}$, MDolores Carmona ${ }^{3}$, Sabina Sánchez-Hernández ${ }^{1}$, Araceli AguilarGonzález $^{1,4}$, María Castella ${ }^{5}$, Manel Juan ${ }^{5}$, Concepción Marañón ${ }^{1}$, Karim Benabdellah ${ }^{1}$, Concha Herrera $^{3}$ and Francisco Martin ${ }^{1 \#}$.

${ }^{1}$ Department of Genomic Medicine, Pfizer-University of Granada-Andalusian Regional Government Centre for Genomics and Oncological Research (GENYO), PTS, Avda. de la Ilustración 114, 18016 Granada, Spain.

${ }^{2}$ LentiStem Biotech, Pfizer-University of Granada-Junta de Andalucía Centre for Genomics and Oncological Research (GENYO), PTS, Avda. de la Ilustración 114, 18016 Granada, Spain.

${ }^{3}$ Maimonides Institute of Biomedical Research in Córdoba (IMIBIC), Cellular Therapy Unit, Reina Sofia University Hospital, University of Córdoba, Córdoba, Spain.

${ }^{4}$ Department of Medicinal and Organic Chemistry, Faculty of Pharmacy, University of Granada, Campus Cartuja, 18071 Granada, Spain.

${ }^{5}$ Department of Hematology, ICMHO, Hospital Clínic de Barcelona, Villarroel 170, 08036 Barcelona, Spain.

*Share authorship

\# Corresponding author: Francisco Martin.

Gene and Cell therapy Unit, Department of Genomic Medicine, Pfizer-University of GranadaAndalusian Regional Government Centre for Genomics and Oncological Research (GENYO), PTS, Avda. de la Ilustración 114, 18016 Granada, Spain.

francisco.martin@genyo.es

Running title: TCR-like LVs for improved CAR-T 


\section{List of abbreviations}

2 ATMP: advanced therapy medical product.

3 B-ALL: B-acute lymphoblastic leukaemia.

4 CAR: Chimeric Antigen Receptor.

5 CMV: Cytomegalovirus.

6 eGFP: enhanced green fluorescent protein.

$7 \quad$ EF1 $\alpha$ : Elongation Factor 1- $\alpha$

8 EMA: European Medicine Agency.

9 FDA: Food and Drug administration.

10 LVs: Lentiviral vectors.

11 LTR: long-terminal repeats

12 MSCV: murine stem cells virus

13 NTD: non-transduced cells.

$14 \mathrm{R} / \mathrm{R}$ : relapsed/ refractory.

15 ScFv: Single chain variable fragment.

16 SFFV: Spleen focus forming virus.

17 TCR: T cell receptor.

18 TCM: T central memory.

19 TEF: T effectors.

20 TEM: T effectors memory.

21 TN/SCM: T naïve/stem cell memory.

22 TRAC: T cell receptor (TCR) constant alpha locus

23 WAS: Wiskott-Aldrich syndrome. 
medRxiv preprint doi: https://doi.org/10.1101/2021.03.17.21253300; this version posted March 20, 2021. The copyright holder for this preprint (which was not certified by peer review) is the author/funder, who has granted medRxiv a license to display the preprint in perpetuity.

It is made available under a CC-BY-NC-ND 4.0 International license .

1

2 Background. Chimeric antigen receptor (CAR) T cells directed against CD19 have achieved

3 impressive outcomes for the treatment of relapsed/refractory B lineage lymphoid neoplasms.

4 However, CAR-T therapy still has important limitations due to severe side effects and the lack

5 of efficiency in $40-50 \%$ of the patients. Most CARs-T products are generated using retroviral

6 vectors with strong promoters. However, high CAR expression levels can lead to tonic

7 signalling, premature exhaustion and over-stimulation of CAR-T cells, reducing efficacy and

8 increasing side effects. TCR-like expression of the CAR through genome editing resulted in

9 enhanced anti-tumour potency, reducing tonic signalling and improving CAR-T phenotype. In

10 this manuscript, we searched for LVs that mimic the TCR expression pattern as a closer-to-

11 clinic alternative for the generation of improved CAR-T cells.

12 Methods. Different LVs containing viral and human promoters were analysed to select those 13 that closely mimic a TCR-like kinetic profile upon T-cell activation. WAS gene proximal 14 promoter-driven LVs (AW-LVs) were selected to express a second generation 4-1BB $\alpha \mathrm{CD} 19$ 15 CAR (ARI-0001) into T cells to generate AWARI CAR-T cells. TCR-like AWARI and EF1 $\alpha$ 16 driven ARI CAR $\mathrm{T}$ cells were analysed for in vitro and in vivo killing efficiency using 17 leukaemia and lymphoma cellular models. Tonic signalling, exhaustion markers and phenotype cells was performed in a CliniMACs Prodigy bioreactor.

20 Results. Our data showed that LVs expressing the transgene through the WAS gene proximal 21 promoter mimic very closely the TCR (CD3) expression pattern kinetic upon TCR stimulation or antigen encounter. Compared to EF1 $\alpha$-driven ARI CAR-T cells, AWARI CAR-T cells exhibited a higher proportion of naïve/stem cell memory $\mathrm{T}$ cells with less exhausted phenotype after efficient killing of CD19+ cells both in vitro and in vivo. AWARI CAR-T cells also showed lower tonic signalling and reduced secretion of pro-inflammatory cytokines and were efficiently manufactured in large-scale GMP-like conditions. 
medRxiv preprint doi: https://doi.org/10.1101/2021.03.17.21253300; this version posted March 20, 2021. The copyright holder for this preprint (which was not certified by peer review) is the author/funder, who has granted medRxiv a license to display the preprint in perpetuity.

It is made available under a CC-BY-NC-ND 4.0 International license .

1 Conclusions. WAS-gene-promoter driven LVs can be used to generate physiological 4-1BB-

2 CAR-T cell products with lower tonic signalling, improved phenotype and a safer profile. We

3 propose the use of TCR-like LVs as an alternative to strong-promoter driven LVs for the

4 generation of CAR-T products.

$5 \quad$ Keywords

6 CAR-T; Physiological expression; TCR-like expression; Lentiviral vectors; tonic signalling;

7 Pro-inflammatory cytokines, Exhaustion; CAR silencing; WAS gene promoter; Stem Cell

8 Memory T cells.

\section{BACKGROUND}

11 Chimeric antigen receptor (CAR) $\mathrm{T}$ cells have become one of the most promising approaches

12 for the treatment of cancer in particular for B lineage lymphoid neoplasms using $\alpha$ CD19-CAR-T

13 cells, as emphasized with four FDA/EMA-approved Advance Therapy Medicinal Products

14 (ATMPs): tisagenlecleucel (Kymriah, Novartis), axicabtageneciloleucel (Yescarta, Kite-Gilead),

15 brexucabtagene autoleucel (Tecartus, Kite-Gilead) and lisocabtagenemaraleucel (Breyanzi,

16 Bristol Myers Squibb). However, in spite of the impressive results of $\alpha$ CD19-CAR-T cells,

17 there are still several aspects that must be improved. Aggressive severe side effects due to CAR-

$18 \mathrm{~T}$ overstimulation, such as cytokine release syndrome (CRS) and neuroinflammation are

19 common among treated patients and can lead to fatal outcomes. Furthermore, sustained

20 complete remissions range from $62 \%$ to $42 \%$ for patients treated with commercial ATMPs,

21 evidencing much room for improvement ${ }^{1}$.

22 Different works have uncovered the importance of controlling CAR expression levels at the 23 surface of the CAR-T cells in order to optimize its therapeutic activity ${ }^{2-4}$. In spite of this, all

24 four approved ATMPs approved and most of those that are been tested in ongoing clinical trials

25 use autologous $\mathrm{T}$ cells transduced with retroviral vectors expressing a $\alpha \mathrm{CD} 19-\mathrm{CAR}$ through

26 constitutive, strong promoters such as the human EF1 $\alpha$ and the murine stem cell virus LTR 
1 (MSCV). High CARs concentrations on the T cell surface can result in spontaneous clustering

2 of the CARs (independent of the ligand) leading to tonic-signalling ${ }^{4}$. This tonic signalling can

3 affect safety (pro-inflammatory cytokines secretion in non-target tissues) and efficacy

4 (premature exhaustion due to continuous proliferation) of CAR-T cells $\mathrm{s}^{3-5}$. Furthermore, high-

5 density and constitutive CAR presence on the T cell surface can also lead to overstimulation

6 upon antigen recognition that also affect safety (excess of pro-inflammatory cytokine secretion)

7 and efficacy (early exhaustion, apoptosis and loss of $\mathrm{T}_{\mathrm{N} / \mathrm{SCM}}$ phenotype) of the CAR-T cells ${ }^{2,3}$.

8 In this direction, Eyquem et al. generated CAR-T cells expressing the $\alpha \mathrm{CD} 19-28 \zeta$ CAR through

9 the endogenous $\mathrm{T}$ cell receptor constant alpha chain (TRAC) locus using CRISPR/Cas9 ${ }^{2}$. In this

10 manuscript, the authors concluded that tight transcriptional regulation of CAR expression,

11 lowering CAR levels upon target binding and recovering 1-3 days later, was critical for optimal

12 CAR-T performance. However, despite the great potential of genome editing tools for

13 therapeutic applications, there are still several technological and safety issues that need to be

14 solved before the approval of genome edited cells as ATMPs.

15 Contrary to genome editing tools, lentiviral vectors (LVs) derived from HIV-1 have already been approved by the FDA and EMA (Kymriah, Breyanzi and Zynteglo). Latest generation LVs are very resistant to transgene silencing ${ }^{6,7}$, and allow the control of the transgene through physiological or drug inducible promoters ${ }^{8-13}$. We therefore searched for LVs that express transgenes on T cells following a TCR expression kinetic. Since the TRAC promoter in human mature $\mathrm{T}$ cells is not well defined, we focus in a well-defined promoter that controls the expression of the WASP protein, which is involved in the formation of the immunological synapse and in translating TCR signals to several T cells functions ${ }^{14,15}$. We reason that WASpromoter driven $\mathrm{LVs}{ }^{81116}$ could be an interesting option to express CARs due to their moderate expression levels and the functional relationship with the TCR. Here we showed that, indeed, WAS-promoter driven LVs partially mimicked the TCR expression kinetic both in eGFP- and

26 CAR-expressing LVs, with a small down-regulation upon stimulation and recovering basal 
medRxiv preprint doi: https://doi.org/10.1101/2021.03.17.21253300; this version posted March 20, 2021. The copyright holder for this preprint (which was not certified by peer review) is the author/funder, who has granted medRxiv a license to display the preprint in perpetuity.

It is made available under a CC-BY-NC-ND 4.0 International license .

1 analysed potential improvements compared to standard CAR-T cells expressing the CAR

2 through strong promoters. TCR-like expression of a $\alpha \mathrm{CD} 19-\mathrm{CAR}$ lead to lower tonic signalling

3 in the absence of antigen as well as a better response in its presence, with lower exhaustion

4 markers, lower proinflammatory cytokine secretion and improved phenotype both in vitro and

5 in vivo.

6 MATERIALS and METHODS

7 Cell culture

8 Nalm6 (ATCC® CRL-3273), Namalwa (ATCC® CRL-1432), Jurkat (ATCC® TIB-152), HL-

960 (ATCC® CCL-240) and HEK-293T (ATCC® CRL-11268) cells were cultured as described

10 elsewhere. Namalwa and Nalm6 were modified to express enhanced GFP (eGFP) and

11 Nanoluciferase (NanoLuc) using the SELWP, as described previously ${ }^{17}$.

\section{Human samples}

14 Primary $\mathrm{T}$ cells were isolated from fresh or frozen apheresis products obtained from healthy 15 donors at the Hematology Department of the Hospital Universitario Reina Sofía (Córdoba, 16 Spain). All donors gave their written informed consent and the study was performed according 17 to the guidelines of the local ethics committee and complies with the requirements regarding 18 quality and safety for donation, obtaining, storage, distribution, and preservation of human cells 19 and tissues under the Spanish specific regulation (RD-L 9/2014). Pan-T cells were isolated by 20 negative selection using immunomagnetic beads (Pan T cell Isolation Kit, Miltenyi Biotec) and 21 following MACSExpress Separator (Miltenyi Biotec) or AutoMACs Pro Separator's (Miltenyi 22 Biotec) protocol and cultured in TexMACS (Miltenyi Biotec) supplemented with $20 \mathrm{UI} / \mathrm{ml}$ of 23 IL-2 (Miltenyi Biotec). T cells were activated with T Cell TransAct (Miltenyi Biotec).

\section{$24 \quad$ Plasmid constructs}

25 To construct the SELWP vector, a self-inactivated (SIN) LV expressing eGFP and NanoLuc 26 under the spleen focus-forming virus (SFFV) promoter, an eGFP-P2A-NanoLuc (NanoLuc 
1 sequence obtained from GeneBank accession: JQ437370. Nucleotides 100-616) flanked by

2 AscI/SbfI restriction sites was designed and synthesized by Genscript (Genscript USA Inc. NY,

3 U.S.A). The eGFP-P2A-NLuc was cloned into the SEWP LV ${ }^{18}$ by standard molecular biology

4 techniques to obtain the SELWP.

5 We used self-inactivated LVs-driven eGFP already available in our laboratory. $\mathrm{SE}^{16}, \mathrm{CEWP}^{10}$

6 and EFEWP (our laboratory) driving eGFP under the control of SFFV, cytomegalovirus, and

7 EF1a promoters, respectively. WAS-promoter based LVs: WE-LVs harbours $0.5 \mathrm{~kb}$ of the WAS

8 proximal promoter ${ }^{16}$, and the AWE-LVs include $0.5 \mathrm{~kb}$ of the WAS proximal promoter and 0.38

$9 \mathrm{~kb}$ of the alternative promoter ${ }^{8}$.

10 For AWARI LVs generation, the AW promoter were obtained from the $\mathrm{AWE}^{8}$ by ClaI / BamHI

11 and inserted into the ARI-0001 plasmid $^{19}$, replacing the EF1 $\alpha$ promoter.

\section{Lentiviral vector production and titration}

13 Lentiviral vectors were generated by co-transfection of HEK-293T cells with the plasmid of 14 interest, the plasmid pCMVDR8.91and the p-MD-G plasmid as previously described ${ }^{12}$. LVs 15 were concentrated by ultracentrifugation at $90.000 \mathrm{~g}$ for $2 \mathrm{~h}$ at $4^{\circ} \mathrm{C}$, resuspended in TexMACs 16 and storaged at $-80^{\circ} \mathrm{C}$. LVs titters were determined by transducing Jurkat cells with different 17 dilutions of viral supernatant. Percentage of positive cells was determined by flow cytometry 18 and transducing units per $\mathrm{ml}(\mathrm{TU} / \mathrm{ml})$ were estimated according to the formula: $\left(10^{5}\right.$ plated cells $19 \times \%$ of positive cells) $] / \mathrm{ml}$ of $\mathrm{LV}$.

\section{T cell transduction}

22 Activated primary $\mathrm{T}$ cells were transduced with the different LVs at a multiplicity of infection

23 (MOI) of 10 through spinoculation $\left(800 \mathrm{x} \mathrm{g}\right.$ for $60 \mathrm{~min}$ at $32^{\circ} \mathrm{C}$ ). Media was exchanged after 5

24 hours of incubation. At 4-6 days after transduction, the percentage of transduced cells was 25 determined by flow cytometry. 
medRxiv preprint doi: https://doi.org/10.1101/2021.03.17.21253300; this version posted March 20, 2021. The copyright holder for this preprint (which was not certified by peer review) is the author/funder, who has granted medRxiv a license to display the preprint in perpetuity.

It is made available under a CC-BY-NC-ND 4.0 International license .

\section{Expression pattern analysis of LVs on $\mathrm{T}$ cells}

2 For $\mathrm{T}$ cells transduced with eGFP-LVs, $10^{5} \mathrm{~T}$ cells were stimulated with TransAct (Miltenyi

3 Biotec) after 10 days of the initial activation for transduction. Similarly, $10^{4}$ transduced CAR-T

4 cells were stimulated with $10^{4} \mathrm{CD} 19+$ Namalwa-GFP-NLuc cells in order to simulate the

5 CAR/TCR signalling axis in U-bottom 96-wells plates. eGFP or CAR expression was

6 determined at different time-points after stimulation. Cells were stained and fixed with $2 \%$ PFA

7 prior FACS acquisition. Expression was indicated as the ratio of MeFI of positive population

8 against the MeFI of non-transduced total population. Fold change indicates the ratio of

9 expression or percentage related to those values at $0 \mathrm{~h}$.

\section{Flow cytometry}

11 CAR expression was determined with a biotin-conjugated goat anti-murine Fab SP-longer

12 Spacer IgG (Jackson Immunoresearch) and APC-conjugated streptavidin (ThermoFisher). For

13 human $\mathrm{T}$ cell phenotyping the following mAbs were used: CD45RA-PE/FITC (HI-100),

14 CD62L-PE-Cy7 (DREG56), CD3-PerCP-Cy5/APC-780 (OKT3), PD1-APC (MIH4), LAG-3-

15 PE (3DS223H), TIM-3-APC-Cy7 (F38-2E2) all from eBioscience (ThermoFisher). Tonic

16 signalling was determined by intracellular staining with pCD3z-PE (Tyr142, 3ZBR4S) and Fix

$17 \&$ Perm Kit (Nordic Bio). Samples were acquired on a FACSCantoII cytometer. FlowJo

18 software (TreeStar) was used for data analysis.

19 Cytokine secretion of CAR-T cells

20 To analyse cytokine production after $\mathrm{T}$ cells stimulation, $5 \times 10^{4} \mathrm{CAR}-\mathrm{T}$ cells were co-cultured

21 with Namalwa-GFP target cells at ratio 1:1 in TexMACs without any supplement. Supernatants

22 were collected after $24 \mathrm{~h}$ and frozen at $-80^{\circ} \mathrm{C}$. TNF $\alpha$ and IFN $\square$ were measured with anti-human

23 TFN- $\alpha$ Ready-SET-Go! Kit of Affymetrix (eBioscience) and ELISA MAX Deluxe Set

24 (Biolegend) respectively following manufacturer's instructions. 
medRxiv preprint doi: https://doi.org/10.1101/2021.03.17.21253300; this version posted March 20, 2021. The copyright holder for this preprint (which was not certified by peer review) is the author/funder, who has granted medRxiv a license to display the preprint in perpetuity.

It is made available under a CC-BY-NC-ND 4.0 International license .

1

3

4

5

6

\section{Cytotoxicity assay}

Target cells (CD19+), such as Namalwa and Nalm-6 cells expressing GFP-Nluc, and non-target cells (CD19-) HL60 cells (unlabelled), were co-cultured at a concentration of $5 \times 10^{3}$ cells per well in duplicate in 96-well U-bottom plates, and incubated with $\mathrm{T}$ cells at various effectortarget $(\mathrm{E}: \mathrm{T})$ ratios $(0.5: 1,1: 1,2: 1)$ in non-supplemented TexMACs during $16 \mathrm{~h}$ or $48 \mathrm{~h}$ as indicated. Percentage of lysis was determined by flow cytometry related to basal lysis produced by non-transduced T cells. Specific lysis was determined as follows: 1-(\%CD19+ $1 \%$ HL-60 in CAR-T cells condition/ \%CD19+/\%HL-60 in NTD condition) x100.

\section{In vivo xenograft animal model and bioluminescence analysis}

10 to 12 -weeks-old NOD/scid-IL-2Rnull (NSG) mice were inoculated intravenously with $3 \times 10^{5}$ Namalwa-GFP-NLuc cells per mice, and three days later, mice were randomly infused with CAR-T cells $\left(5 \times 10^{6}\right.$ or $\left.10 \times 10^{6}\right)$, non-transduced T cells $\left(5 \times 10^{6}\right.$ or $\left.10 \times 10^{6}\right)$ or PBS in the tail's vein. Re-challenge was assessed by re-inoculating intravenously a new dose of Namalwa-GFPNluc cells. Our experiments are based on a modified randomized block design in which each block receives more than one treatment at different periods. Subjects were randomly assigned to receive the different treatments (PBS, T cells or CAR-T cells). This will allow a comparison between the different treatment groups in pairs (each one compared to the control and each one compared to each other). For the estimation of the sample size in each experiment, we calculated the sample size necessary to obtain a $\mathrm{p} \geq 0.05$ to be of $n \geq 5$ for controls/CAR-T comparison and an $\mathrm{n} \geq 8$ for AWARI/ARI comparisons based on Mayer et $\mathrm{al}^{20}$. For bioluminescence analysis, furimazine (Nano-Glo, Promega) was diluted at 1/60 in PBS and injected intraperitoneally immediately prior to acquisition on an IVIS Spectrum analyzer (Caliper, Perkin Elmer). Images were acquired during 180s, open field, and analysed using the Living Image 3.2 (Perkin Elmer) or AURA Imaging Software 3.2 (Spectral Instruments Imaging). Mice were sacrificed if experiencing a weight loss greater than $20 \%$ or at the indicated days. Samples of blood, bone marrow, liver, spleen and brain were collected. Blood was extracted and diluted $1 / 5$ in EDTA. Cells were obtained from liver and spleen by 
medRxiv preprint doi: https://doi.org/10.1101/2021.03.17.21253300; this version posted March 20, 2021. The copyright holder for this preprint (which was not certified by peer review) is the author/funder, who has granted medRxiv a license to display the preprint in perpetuity.

It is made available under a CC-BY-NC-ND 4.0 International license .

1 mechanical disruption and from bone marrow by the perfusion of both femurs and tibias.

2 Brain's cells were obtained after Percoll-gradient separation. Percentage of surviving Namalwa-

3 GFP-Nluc and T cells (hCD3+) were determined by FACS in the singlet's gate and then in

4 "human cells" gate, which was previously established after acquiring an artificial mixture of

$5 \quad$ Namalwa cells and human T cells used as control.

\section{GMP-like manufacturing of CAR-T cells on CliniMACs Prodigy}

7 Large scale manufacturing of CAR-T cells on CliniMACs Prodigy was carried out under GMP-

8 like conditions into Gene-Cell Therapy cleanrooms of Cell Therapy Unit of Hospital

9 Universitario Reina Sofía (Córdoba, Spain). Two different apheresis from a healthy donor was

10 thawed and around $100 \times 10^{6} \mathrm{~T}$ cells were inoculated into the CliniMACs prodigy bioreactor

11 (Miltenyi Biotec). CD4 and CD8 cells were selected with CD8 and CD4 Reagent (Miltenyi

12 Biotec), cultured with IL-7/IL-15 (Miltenyi Biotec) and activated with $\alpha$ CD3/ $\alpha$ CD28 GMP T

13 cell TransAct (Miltenyi Biotec). At day 2 of the process, these cells were transduced with

14 AWARI-LVs (MOI=5). Cells were cultured in TexMACs GMP medium containing GMP-grade

15 IL-15 and IL-7 (Miltenyi Biotec) for 9 or 10 days. Final product was collected with 100ml of

$16 \mathrm{NaCl} 0,9 \%+0,5 \%$ human serum albumin (HSA).

17 Cells were stained with CD3-APC, CD4-FITC, CD8-APC Vio770, CD14-PE Vio770, CD45-

18 Vioblue (Miltenyi Biotec). To assess the efficiency of transduction CAR-T cells were stained

19 with CD-19 Biotin and Anti-biotin PE (Miltenyi Biotec). Viability was tested by using 7AAD

20 (Miltenyi Biotec). Phenotype was determined with CD45RA-APC (HI100) and CCR7-BV421

21 (2-L1-A RUO) from BD Pharmingen. Cells were acquired on a MACsQuant cytometer

22 (Miltenyi Biotec) and analyzed with MACsQuantify Analysis Software (Miltenyi Biotec).

\section{Data analysis}

24 Statistical analyses were performed using GraphPad 1.6 software (GraphPad Software Inc., La

25 Jolla, CA). Data were expressed as the mean \pm SEM. Each performed statistical test was 
medRxiv preprint doi: https://doi.org/10.1101/2021.03.17.21253300; this version posted March 20, 2021. The copyright holder for this preprint (which was not certified by peer review) is the author/funder, who has granted medRxiv a license to display the preprint in perpetuity.

It is made available under a CC-BY-NC-ND 4.0 International license .

1 indicated in every figure caption. Survival curves were constructed using the Kaplan-Meier

2 method.

3

\section{RESULTS}

5 WAS promoter-driven LVs mimic the TCR expression pattern upon T-cell activation

6 As LVs have already been approved by EMA and the FDA, LVs expressing the CARs with a 7 similar kinetic than the TCR (TCR-like LVs) could be a real alternative to existing LVs to

8 generate more potent and safer CAR-T cells. We first investigated whether WAS-promoter-

9 driven LVs could have a more physiological expression pattern compared to current LVs used

10 for CAR-T cells generation. We generated eGFP-expressing LVs particles from two different

11 WAS-promoter-driven LVs (Fig. 1A, WE and AWE) $)^{8,16}$ and three LVs driven by strong

12 promoters (Fig. 1A, CEWP, SE and EFEWP).

13 In order to analyse if the WAS-promoter-driven LVs mimic the TCR expression pattern, we first 14 studied the CD3 expression levels (Fig. 1B and Fig. S1a) of primary human $\mathrm{T}$ cells after 15 stimulation with $\alpha \mathrm{CD} 3 / \alpha \mathrm{CD} 28$ nanomatrix and CD19+ cells (in CAR+ cells, Fig 1B and Fig 16 S1b) at different time-points. In parallel, T cells transduced with the different eGFP-expressing 17 LVs were stimulated and analysed by flow cytometry as described in Fig. 1A. As it has been reported previously ${ }^{2}, \mathrm{CD} 3$ expression in $\mathrm{T}$ cells decreased soon after stimulation reaching minimal expression at $24 \mathrm{~h} / 48 \mathrm{~h}$ at both protein and mRNA levels and recover basal levels after 5-7 days (Fig 1B, S1a). Contrary to the CD3 expression pattern, all LVs harbouring constitutive-strong promoters (EF1 $\alpha$ (EFEWP), SFFV (SE) and CMV (CEWP)), behaved in an opposite manner, increasing eGFP expression soon after T cell stimulation (Fig. 1C-top panels,

23 1D and 1E-orange line). Interestingly, WAS-promoter driven LVs partially mimicked the TCR expression kinetic, down-regulating eGFP expression upon stimulation that peak at $48 \mathrm{~h}$ and recover basal levels after 7 days (Fig. 1C-bottom panels, 1E-blue and green lines). 
1 We next investigated whether CARs expressed by WAS-promoter driven LVs also followed a

2 TCR-like kinetic. We constructed the AWARI LV (see M\&M for details) based on the ARI-

$30001 \mathrm{LV}$ backbone ${ }^{21}$, a CAR19-BBzz recently approved as ATMP in Spain, which uses the

$4 \quad$ A1B6 clone as scFv (Fig. 1F). We then generated ARI and AWARI CAR-T cells using the ARI

5 and AWARI LVs and analysed their CAR expression kinetic upon activation with CD19+ cells

6 (Fig 1G-left,1H and S1B-left) or $\alpha \mathrm{CD} 3 / \alpha \mathrm{CD} 28$ (Fig 1G-right, 1I and S1B-right). Interestingly,

7 AWARI CAR-T cells showed a down-regulation of CAR levels after antigenic stimulation and

8 a recovery after $48 \mathrm{~h}$ (Fig. 1H, 1I, blue line; Fig. 1G, bottom panel), while ARI CAR-T cells

9 showed a clear increment on CAR levels after T cell activation (Fig. 1H, 1I, green lines, Fig.

10 1G, top panel). A similar behaviour was also observed when using a third generation $\alpha \mathrm{CD} 19$ -

11 CAR-28BBzz (Fig S1C, S1D). Altogether, our results showed that the AW-LVs can be used to

12 generate CAR-T cells expressing the CAR in a TCR-like manner.

TCR-like expression of CAR prevents exhaustion and control proinflammatory cytokines secretion upon antigen exposure in vitro

16 We next compared the behaviour of $2^{\text {nd }}$ generation ARI versus AWARI CAR-T cells. First, we measured basal levels of exhaustion markers (LAG-3, PD1, Tim3) (Fig. 2A) and tonic signalling (phospho-CD3z) (Fig. 2B) in a CD19-independent context. AWARI CAR-T cells expressed significant lower levels of LAG-3 and Tim3 (and also a trend for PD1) (Fig. 2A) and less phosphorylation of CD3z (Figure 2B). Both CAR-T cells efficiently killed CD19+ Nalm6 (B-ALL derived) and Namalwa (Hodgkin's lymphoma derived), without significant differences (Fig. 2C). Interestingly, LAG-3 expression levels were significantly lower in AWARI compared to ARI CAR-T cells after killing Namalwa cells (Fig. 2D, right). In addition, AWARI CAR-T cells secreted lower levels of TNF $\alpha$ and IFN $\gamma$ compared to ARI cells (Fig. 2E), indicating a more controlled proinflammatory activity. We also observed a tendency of increased stem memory $\mathrm{T}$ cells (CD45RA+CD62L+) population in AWARI versus ARI CAR-T 
medRxiv preprint doi: https://doi.org/10.1101/2021.03.17.21253300; this version posted March 20, 2021. The copyright holder for this preprint (which was not certified by peer review) is the author/funder, who has granted medRxiv a license to display the preprint in perpetuity.

It is made available under a CC-BY-NC-ND 4.0 International license .

1 when $3^{\text {rd }}$ generation CARs (CAR19-28BBzz) were expressed with the AW-LVs in terms of

2 lower tonic signalling (Fig S2A) and milder IFN $\gamma$ secretion (Fig. S2B).

4 AWARI CAR-T cells are as efficient as ARI CAR-T cells eradicating CD19+ tumour cells 5 in vivo and maintain a more stem-like phenotype.

6 In vitro cytotoxicity experiments only represent a direct-short term activity of CAR-T cells. We

7 therefore performed a direct comparison of the anti-tumour activity of ARI versus AWARI

8 CAR-T cells in a xenograft mice model of human lymphoma using two different CAR-T doses

9 and a re-challenge after first lymphoma cells clearance (Fig. 3A, See M\&M for details). Both

10 CAR-T cells efficiently eliminated Namalwa tumour cells in treated mice with both doses (Figs.

11 3B, 3C and Fig. S3A). However, a small amount of Namalwa cells (less than <5\%) were

12 detected in liver of some ARI-mice and in brain of some AWARI-mice treated with the low

13 dose (Fig. 3C, left panels). Importantly, CAR expression driven by the two vectors was

14 maintained in all the organs after sacrifice (Fig. 3D), even with a second-challenge, when

15 compared to those ex-vivo levels prior to infusion (Fig. S3B), indicating no promoter silencing.

16 After showing the same therapeutic efficacy, we investigated potential differences in CAR-T

17 cell phenotype after tumour clearance. Interestingly, AWARI-CAR-T cells showed a higher

18 proportion of memory ( $\mathrm{T}_{\mathrm{CM}} \mathrm{CD} 45 \mathrm{RA}-\mathrm{CD} 62 \mathrm{~L}+$ ) and stem memory $\left(\mathrm{T}_{\mathrm{SCM}}\right.$ : CD45RA+CD62L+)

19 (Fig. 3D) cells in spleen, bone marrow (BM), blood and liver when compared to ARI-treated

20 mice (Fig.3E, 3F). Specially after re-challenge (inner circle, Fig. 3E), $\mathrm{T}_{\mathrm{SCM}}$ population of

21 AWARI-CAR-T cells was increased in spleen and liver and $\mathrm{T}_{\mathrm{CM}}$ subset in $\mathrm{BM}$ and brain. In

22 order to further characterize the potential differences, we cultured the cells from processed

23 spleens during $48 \mathrm{~h}$ in vitro with $200 \mathrm{UI} / \mathrm{ml}$ of IL-2 in TexMACs medium (Fig. 3G), and we

24 confirmed an increment in T cell memory populations in AWARI-derived spleens (Fig. 3H, 3I)

25 and a tendency to have lower expression of exhaustion markers (PD1+LAG3+) (Fig. 3H, 3J). 
medRxiv preprint doi: https://doi.org/10.1101/2021.03.17.21253300; this version posted March 20, 2021. The copyright holder for this preprint (which was not certified by peer review) is the author/funder, who has granted medRxiv a license to display the preprint in perpetuity.

It is made available under a CC-BY-NC-ND 4.0 International license .

1

2 Before translation of AW-LV to ATMP production for clinical applications, it is important to

3 demonstrate their performance for large-scale automated manufacturing. We therefore used

4 laboratory grade AWARI LVs to generate two batches of CAR-T cells (\#01 and \#02) in the

5 CliniMACs Prodigy Bioreactor (Miltenyi Biotec) under GMP conditions (see M\&M). Samples

6 at days 7 and 10 for batch \#01, and 6 and 9 days for batch \#02 (Fig. 4A) were collected to study

7 CAR expression (Fig. 4B), viability, expansion (Fig 4C), CD4/CD8 ratio (Fig. 4D), phenotype

8 (Fig. 4E), and in vitro lytic activity (Fig. 4F). In both productions processes, cells were

9 efficiently expanded, with more CD4+ than CD8+ CAR+ cells and prominent $\mathrm{T}_{\mathrm{N}} / \mathrm{SCM}(\mathrm{CCR} 7+$

$10 \mathrm{CD} 62 \mathrm{~L}+)$ subset $(44,85 \pm 0.07 \%)$ at day 7 or day 6 , that were drastically reduced at final day of the production $(16,55 \pm 13.93 \%)$, turning into $\mathrm{T}_{\mathrm{CM}}$ cells but with minimal effector and effector memory populations (Fig. 4E). As described for other CAR-T cell products, lower expansion times rendered more potent AWARI CAR-T cells (Fig. 4F). All these results point out to the AWARI LVs as a valuable tool for a future clinical trial, although improvements in its lentiviral backbone could further increase transduction efficacy in order to lower costs and time of production.

\section{Large-scaled manufactured AWARI CAR-T cells products are highly efficient for tumour} clearance and maintain good levels of $\mathbf{T}_{\mathrm{N} / \mathrm{SCM}}$ cells in vivo.

Finally, we performed a detailed analysis of large-scale manufactured AWARI CAR-T cells in terms of their in vivo anti-tumour efficacy and their phenotype after isolation from treated mice (Fig. 5) for both \#01 (blue dots) and \#02 (green dots) CliniMACS batches. Anti-tumour activity of both AWARI CAR-T cells products were analysed in the Namalwa xenograft mice model as depicted in Fig 5A. Survival (Fig. 5B) and tumour progression (Figs. 5C and 5D) were monitored up to 28-30 days post-treatment showing a strong anti-tumour activity of the AWARI CAR-T cells with $100 \%$ survival and undetectable tumour cells in treated mice (Figs. 5C, 5D and Fig, S4A). Control PBS and NTD- inoculated mice developed the disease at similar rates 
1 and the majority required to be sacrificed for compassionate reasons at days 13-16. At this time

2 point, the stemness of human CAR-T cells of two AWARI-treated mice (Fig. 5F top panel,

3 S4C) in \#01 experiment was clearly maintained. New Namalwa cells were inoculated in

4 AWARI -T cells-treated mice and also in new mice ("New PBS"). Re-challenged AWARI-mice

5 remained tumour-free through the duration of the experiment as did the follow-up group.

6 Similar results were observed in both productions (Fig. 5C, 5D, S4A). The percentage of CAR+

7 cells (Fig 5E) was maintained before (ex-vivo) and after in vivo elimination of Namalwa cells in

8 the xenograf model with a slight increase in some of the organs (Fig. S4b). Importantly, the

9 phenotypic analysis confirmed the presence of a high proportion of $\mathrm{T}_{\mathrm{SCM}} / \mathrm{T}_{\mathrm{CM}}$ populations (Fig.

$10 \mathbf{5 E}, \mathbf{5 F}, \mathbf{S 4 D})$ at the end point of rechallenged and non-rechallenged mice. However, a

11 significant reduction of these populations was observed from day 13 to day 30 (Fig. 5F top

12 panel, S4C). This data confirmed the in vitro (Fig. S2) and in vivo (Fig. 3) results showing that

13 the expression of the ARI-CAR19-BBzz through a TCR-like promoter (AWARI-CAR-T cells)

14 maintains the proportion of $\mathrm{T}_{\mathrm{SCM}} / \mathrm{T}_{\mathrm{CM}} \mathrm{CAR}-\mathrm{T}$ cells upon antigen encounter. 
1

\section{DISCUSSION}

$2 \alpha \mathrm{CD} 19$ CAR-T cells have achieved impressive therapeutic benefits in R/R B lineage lymphoid

3 neoplasms, leading to the approval of Kymriah, Yescarta, Tecartus and Breyanzi and over 800

4 clinical trials around the globe. Most of these studies have used autologous T cells that are gene

5 modified by retrovirus-based vectors to express the CAR through a strong promoter (often the

$6 \mathrm{EF} 1 \alpha$ or MSCV promoters). However, CAR-T therapy still has important limitations due to

7 severe side effects and the lack of complete cures in 40-62\% of the CD19+ lymphomas ${ }^{1}$ and

8 most solid tumours ${ }^{22,23}$. Improvements in CAR structure (scFV, hinge/spacer, costimulatory

9 domains, bi-especific or multispecific CARs, etc) T cell composition or combinational therapies

10 have already shown improved results ${ }^{24}$. New approaches to improve CAR-T efficacy and/or

11 safety include the control of CAR activity and or other molecules ${ }^{13}$ and mechanism to avoid

12 immune-reactions against the CAR-T cells ${ }^{25}$.

13 There are several evidences indicating that high levels and continuous expression of the CAR 14 can be deleterious for the efficacy and safety of the CAR-T products ${ }^{2-4}$. The loss of efficacy

15 comes in part from the early exhaustion and/or apoptosis of the CAR-T cells due to an excess of

16 CAR signalling after antigen encounter ${ }^{26}$. Strong and unregulated CAR expression also increase

17 tonic signalling in the absence of target antigen ${ }^{4}$ promoting exhaustion $^{3,5}$. On the other side,

safety issues due to CAR overexpression relates to the increased antigen-independent tonic signalling and to over-stimulation of CAR-T cells that generate CRS. Using genome editing technologies, Eyquem et al. demonstrated that TCR-like expression of CARs resulted in lower tonic signalling, reduced CAR-T exhaustion and increased proportion of TSM/TN CAR-T cells, resulting in improved anti-tumour activity ${ }^{2}$. These authors also showed that low expression was not enough to achieve optimal CAR-T products, concluding that a down-regulation of the CAR upon antigen encounter was required for optimal CAR-T performance.

In this manuscript we investigated whether LVs can be used to obtain a TCR-like expression

kinetics that could also result in an improved CAR-T cell product. Our search for human 
1 promoters that could mimic the TCR expression pattern pointed to the TRAC locus, however,

2 the TRAC promoter in mature human $\mathrm{T}$ cells is not well defined. We therefore focus on the

3 WAS gene promoter because WASP protein is only expressed in hematopoietic cells, is involved

4 in the formation of the immunological synapse and acts as an adaptor of TCR signals ${ }^{14,15}$. We

5 have previously developed different WAS-gene based promoters and identified the AW

6 promoter, harbouring fragments from the alternative and proximal promoter, as the best option

7 to express transgenes in hematopoietic cells ${ }^{8,11,16}$. Here we showed that, indeed, WAS-promoter

8 driven LVs (AW-LVs) partially mimicked the TCR expression kinetic, with a small down-

9 regulation upon stimulation and recovering basal levels in 5-7 days.

10 Based on the ability of AW-LVs to mimic TCR expression pattern on T cells, we investigated 11 whether 4-1BB-CAR-T cells generated with this "physiological" LVs have a better behaviour 12 compared to that generated with LVs harbouring strong or viral promoters. Although in terms of 13 in vitro or in vivo anti-tumour activity we could not detect significant differences with EF1 $\alpha$ -

14 driven CAR-T cells, AW-CAR-T cells exhibited lower tonic signalling and a better phenotype 15 after efficient killing of CD19+ cells, with reduced secretion of pro-inflammatory cytokines.

16 These data is largely in agreement with the observations of Eyquem et al. using genome editing

17 technologies to express the CAR through the TRAC locus ${ }^{2}$. However, these authors also showed 18 improved in vivo anti-tumour activity ${ }^{2}$. The differences in the tumour model (Nalm6 versus 19 Namalwa) as well as in the CAR signalling domain (CD28 versus 4-1BB) and scFv (FMC63 20 versus A3B1) could explain the observed differences. Indeed, the potential deleterious effects of

21 CAR over-expression and tonic signalling are highly influenced by the CAR configuration ${ }^{2,4}$.

22 For instance, replacing CD28 with the 4-1BB costimulatory domain reversed exhaustion in

23 CAR T cells and improved its persistence and therapeutic efficacy ${ }^{27}$. The good behaviour of

24 EF1 $\alpha$-driven 4-1BB-CARs T cells and the experimental limitations derived by the graft versus

25 host disease (GVHD) caused by the administration of the CAR-T cells can explain the absence

26 of increased therapeutic efficacy in our animal models. 
1 In spite of the good behaviour of 4-1BB-CARs, Gomes-Silva et al demonstrated that very high

2 expression levels of 4-1BB-CARs also lead to apoptosis and limit CAR-T cells expansion ${ }^{4}$. The

3 same authors also showed that lowering it expression levels by using EF1 $\alpha$-driven LVs instead

4 of LTR-driven $\square$-retroviral vector, improved phenotype, expansion potential and therapeutic

5 efficacy. These studies showed that EF1 $\alpha$-driven LVs already generate a good CAR product for

6 some 4-1BB-CARs. Here we show that TCR-like expression can further improve 4-1BB-CAR-

7 T products, in particular for the ARI-0001, by maintaining a better phenotype and controlling

8 tonic signalling and pro-inflammatory cytokine secretion.

9 An important aspect to consider in CAR-T cells is the potential side effects due to 10 overstimulation and/or inadequate stimulation. Severe CRS (grades 3 or 4) is an important

11 hallmark in CD19+ that can compromise efficacy and lead to life-threatening conditions ${ }^{28,29}$.

12 Upon tumour cell encounter, CAR-T cells release different pro-inflammatory cytokines such as

13 TNF $\alpha$, IFN $\square$, IL-1 and GM-CSF that leads to macrophage recruitment and activation causing a

14 dangerous cytokine storm involving IL-6 and GM-CSF ${ }^{30,31}$. It has also been demonstrated that

15 activation of macrophages through CD40/CD40L, CD69 and LAG-3 also contributes to massive

16 activation ${ }^{29}$. Although CRS can be managed with corticosteroids and anti-IL6R (Tocilizumab),

17 these interventions also block $\mathrm{T}$ cell activation compromising CAR-T efficacy ${ }^{29}$. In this

18 manuscript, we have shown that CAR-T cells generated with AW-LVs exhibit a milder secretion of TNF $\alpha$ and IFN $\square$ after tumour cells encounter. In addition, we noted that LAG-3

20 expression was reduced after Namalwa interaction which suggests that AW-CAR-T cells could

21 lower the risk of CRS.

22 We finally investigated the feasibility of generating a viable CAR-T cell product for clinical

23 translation. Here, we have demonstrated that it is feasible to generate TCR-like CAR-T cells in

24 a CliniMACs Prodigy, with high cell viability, predominant stem and CM populations and

25 potent in vitro and in vivo anti-tumour activity. In contrast and consistent with our comparative

26 results, ARI-0001 generated more memory and effector memory population ${ }^{19}$, highlighting

27 another potential advantage of AW-CAR-T cells during the manufacturing process. On the other 
1 hand, the efficacy of transduction was lower compared to ARI ( 18.4\% vs 30.6\%), suggesting

2 that a future optimization of the AWARI LV backbone could further improve the manufacturing

3 process of AW-CAR-T cells.

4 Taken all together, we propose the use of AW-LVs as an alternative platform for the

5 manufacturing of CAR-T cells in order to provide better efficacies and/or safety of the final

6 products. The final benefits of expressing different CARs through the AW promoter will need to

7 be determined in each case.

\section{Conclusions}

10 In this work we showed that LVs expressing the transgene through the WAS gene proximal

11 promoter mimic very closely the TCR expression pattern kinetic in T cells. 4-1BB-CAR-T cells

12 generated with WAS-promoter-driven LVs (AWARI CAR-T) exhibited a higher proportion of

13 Naïve/Stem Cell Memory T cells, less exhausted phenotype, lower tonic signalling and reduced

14 secretion of pro-inflammatory cytokines compared to EF1-driven ARI CAR-T. Finally, AWARI

15 CAR-T cells were efficiently manufactured in large-scale GMP-like conditions. Altogether, our data showed that the AW-LVs can be used to generate improved, physiological 4-1BB-CAR-T

17 cell products and propose these LVs as efficient tools for the generation of clinical-grade TCR-

18 like CAR-T cells.

\section{DECLARATIONS}

\section{Ethics approval and consent to participate}

22 All donors from the Haematology Unit of Hospital Reina Sofía, Córdoba (Spain) gave their

23 written informed consent and the study was performed according to the established guidelines

24 of in the approved by the Regional Government Junta de Andalucía-Consejeria de Salud (date 
1 of approval: 22/02/2019, signed by $\mathrm{D}^{\mathrm{a}}$ Cristina Lucía Dávila Fajardo as secretary of the

2 Research Ethics Committee), that comply with the requirements regarding quality and safety for

3 donation, obtaining, storage, distribution, and preservation of human cells and tissues under the

4 Spanish specific regulation (RD 9/2014) and International Conference of Good Clinical

5 Practice. All the experiments involving animals were performed according to a protocol

6 approved by the Institutional Animal Care and Use Committee of the University of Granada

$7(13 / 12 / 2016 / 181)$ were in accordance with the European Convention for the Protection of

8 Vertebrate Animals used for Experimental and Other Scientific Purposes (CETS \# 123) and the

9 specific Spanish law (R.D. 53/2013). Subjects were randomly assigned to receive the different

10 treatments and sample size estimation was calculated based on Mayer et $\mathrm{al}^{20}$.

\section{Consent for publication}

12 All the authors consent the publication of this manuscript.

\section{Availability of data and material}

14 All data relevant to the study are included in the article or uploaded as online supplemental

15 information. Figures were created with Biorender.com.

\section{Competing interests}

17 FMM, MTM, NMP, PM and KB are inventors of a patent for AW promoter for CAR-T cells

18 applications. P.J.L is contractually associated to LentiStem Biotech, a Spin-Off company that

19 has the license of that patent. The rest of the authors declare that the research was conducted in

20 the absence of other commercial or financial relationships that could be construed as a potential

21 conflict of interest.

\section{Funding}

23 This study was funded by the Spanish ISCIII Health Research Fund and the European Regional

24 Development Fund (FEDER) through research grants PI12/01097, PI15/02015, PI18/00337 
medRxiv preprint doi: https://doi.org/10.1101/2021.03.17.21253300; this version posted March 20, 2021. The copyright holder for this preprint (which was not certified by peer review) is the author/funder, who has granted medRxiv a license to display the preprint in perpetuity.

It is made available under a CC-BY-NC-ND 4.0 International license .

1 (F.M.), PI18/00330 (K.B.) and PI17/00672 (P.M.); The CECEyU and CSyF of the Junta de

2 Andalucía FEDER/European Cohesion Fund (FSE) for Andalusia provided the following

3 research grants: 2016000073391-TRA, 2016000073332-TRA, PI-57069, PAIDI-Bio326,

4 CARTPI-0001-201 (F.M.), PI-0014-2016 (K.B) and PEER-0286-2019 (P.M.), PE-0223-2018;

5 The Ministerio de Ciencia, Innovación y Universidades (CDTI) to F.M. (00123009 / SNEO-

6 20191072). K.B. and C.M held Nicolas Monardes contracts from regional Ministry of Health

7 (\#0006/2018 and C2-0002-2019 respectively). M.T.M., N.M.P and A.A.G. are funded by

8 Spanish Ministry of Education and Science through fellowships FPU16/05467, FPU17/02268

9 and FPU17/04327 respectively. P.J.L is funded through an industrial doctorate MCI DIN2018-

10010180 to LentiStem Biotech. P.M is funded by Fundación Andaluza Progreso y Salud. M.C.G

11 is funded by Spanish Ministry of Education and Science through fellowship GJ (PEJ-2018-

12 001760-A). MDC is funded by the grant PE-0223-2018 CSyF of the Junta de Andalucia.

13 M.T.M., N.P.M., P.L.J.L., M.C.G. and A.G.G. are PhD students from the Biomedicine

14 Programme of the University of Granada (Spain).

\section{Authors' contributions}

16 MTM and NMP designed and performed experiments, analysed data and wrote the manuscript.

17 PLJL performed and analysed experiments and critical review of the manuscript. PM contributed to animal experiments. MCG and KP contributed to T cells isolation and revised the

19 manuscript. RJM and SN designed and produced CliniMACs Prodigy large scale CAR-T cells

20 production process. RJM, SN and MDC performed the phenotypic characterization of

21 CliniMACs-derived products. SSH and AAG contributed to AWARI LVs production. MC and

22 MJ provided ARI-0001 LV and critical review. CM provided material and critical review. KB

23 provided funding and critical review. $\mathrm{CH}$ provided funding and critical review of the

24 manuscript. FM conceals the project, designed experiments, analysed data, provides the main

25 funding and wrote the manuscript.

\section{Acknowledgements}


medRxiv preprint doi: https://doi.org/10.1101/2021.03.17.21253300; this version posted March 20, 2021. The copyright holder for this preprint (which was not certified by peer review) is the author/funder, who has granted medRxiv a license to display the preprint in perpetuity.

It is made available under a CC-BY-NC-ND 4.0 International license .

We thank Ana Fernández-Ibáñez for her support with the IVIS Spectrum Analyzer, Nieves

Álvarez for her help of ELISA assays. We also thank GENYO’s supporting units.

(1)

(1)

\section{References}

1. Vitale C, Strati P. CAR T-Cell Therapy for B-Cell non-Hodgkin Lymphoma and Chronic Lymphocytic Leukemia: Clinical Trials and Real-World Experiences. Front Oncol 2020;10:849.

2. Eyquem J, Mansilla-Soto J, Giavridis T, et al. Targeting a CAR to the TRAC locus with CRISPR/Cas9 enhances tumour rejection. Nature 2017;543(7643):113-17.

3. Frigault MJ, Lee J, Basil MC, et al. Identification of chimeric antigen receptors that mediate constitutive or inducible proliferation of T cells. Cancer Immunol Res 2015;3(4):35667.

4. Gomes-Silva D, Mukherjee M, Srinivasan M, et al. Tonic 4-1BB Costimulation in Chimeric Antigen Receptors Impedes $\mathrm{T}$ Cell Survival and Is Vector-Dependent. Cell Rep 2017;21(1):17-26.

5. Ajina A, Maher J. Strategies to Address Chimeric Antigen Receptor Tonic Signaling. Mol Cancer Ther 2018;17(9):1795-815.

6. Benabdellah K, Gutierrez-Guerrero A, Cobo M, et al. A chimeric HS4-SAR insulator (IS2) that prevents silencing and enhances expression of lentiviral vectors in pluripotent stem cells. PLoS ONE 2014;9(1):e84268.

7. Naldini L, Trono D, Verma IM. Lentiviral vectors, two decades later. Science 2016;353(6304):1101-2.

8. Frecha C, Toscano MG, Costa C, et al. Improved lentiviral vectors for Wiskott-Aldrich syndrome gene therapy mimic endogenous expression profiles throughout haematopoiesis. Gene Ther 2008;15(12):930-41.

9. Romero Z, Torres S, Cobo M, et al. A tissue-specific, activation-inducible, lentiviral vector regulated by human CD40L proximal promoter sequences. Gene Ther 2011;18(4):36471.

10. Benabdellah K, Cobo M, Munoz P, et al. Development of an all-in-one lentiviral vector system based on the original TetR for the easy generation of Tet-ON cell lines. PLoS ONE 2011;6(8):e23734.

11. Munoz P, Tristan-Manzano M, Sanchez-Gilabert A, et al. WAS Promoter-Driven Lentiviral Vectors Mimic Closely the Lopsided WASP Expression during Megakaryocytic Differentiation. Mol Ther Methods Clin Dev 2020;19:220-35.

12. Benabdellah K, Munoz P, Cobo M, et al. Lent-On-Plus Lentiviral vectors for conditional expression in human stem cells. Sci Rep 2016;6:37289.

13. Tristan-Manzano M, Justicia-Lirio P, Maldonado-Perez N, et al. Externally-Controlled Systems for Immunotherapy: From Bench to Bedside. Front Immunol 2020;11:2044.

14. Calvez R, Lafouresse F, De Meester J, et al. The Wiskott-Aldrich syndrome protein permits assembly of a focused immunological synapse enabling sustained T-cell receptor signaling. Haematologica 2011;96(10):1415-23.

15. Cotta-de-Almeida V, Dupre L, Guipouy D, et al. Signal Integration during T Lymphocyte Activation and Function: Lessons from the Wiskott-Aldrich Syndrome. Front Immunol 2015;6:47. 
16. Martin F, Toscano MG, Blundell M, et al. Lentiviral vectors transcriptionally targeted to hematopoietic cells by WASP gene proximal promoter sequences. Gene Ther 2005;12(8):715-23.

17. Navarro-Marchal SG-L, Carmen; Entrena, Jose-Manuel; Ruiz-Alcala, Gloria; TristánManzano, Maria; Martín, Francisco; Pérez-Victoria, Ignacio; Peula-Garcia, José Manuel; Marchal, Juan A. Anti-CD44-conjugated olive oil liquid nanocapsules for targeting pancreatic cancer stem cells. Biomacromolecules 2021.

18. Demaison C, Parsley K, Brouns G, et al. High-level transduction and gene expression in hematopoietic repopulating cells using a human immunodeficiency [correction of imunodeficiency] virus type 1-based lentiviral vector containing an internal spleen focus forming virus promoter. Hum Gene Ther 2002;13(7):803-13.

19. Castella M, Caballero-Banos M, Ortiz-Maldonado V, et al. Point-Of-Care CAR T-Cell Production (ARI-0001) Using a Closed Semi-automatic Bioreactor: Experience From an Academic Phase I Clinical Trial. Front Immunol 2020;11:482.

20. Mayer B, Stahl V, Kron M. The use of gatekeeping procedures in the statistical planning of animal experiments. Altern Lab Anim 2017;45(6):317-28.

21. Castella M, Boronat A, Martin-Ibanez R, et al. Development of a Novel Anti-CD19 Chimeric Antigen Receptor: A Paradigm for an Affordable CAR T Cell Production at Academic Institutions. Mol Ther Methods Clin Dev 2019;12:134-44.

22. Marofi F, Motavalli R, Safonov VA, et al. CAR T cells in solid tumors: challenges and opportunities. Stem Cell Res Ther 2021;12(1):81.

23. Martinez M, Moon EK. CAR T Cells for Solid Tumors: New Strategies for Finding, Infiltrating, and Surviving in the Tumor Microenvironment. Front Immunol 2019;10:128.

24. Rodriguez-Garcia A, Palazon A, Noguera-Ortega E, et al. CAR-T Cells Hit the Tumor Microenvironment: Strategies to Overcome Tumor Escape. Front Immunol 2020;11:1109.

25. Wagner DL, Fritsche E, Pulsipher MA, et al. Immunogenicity of CAR T cells in cancer therapy. Nat Rev Clin Oncol 2021.

26. Finney OC, Brakke HM, Rawlings-Rhea S, et al. CD19 CAR T cell product and disease attributes predict leukemia remission durability. J Clin Invest 2019;129(5):2123-32.

27. Long AH, Haso WM, Shern JF, et al. 4-1BB costimulation ameliorates T cell exhaustion induced by tonic signaling of chimeric antigen receptors. Nat Med 2015;21(6):581-90.

28. Lee DW, Santomasso BD, Locke FL, et al. ASTCT Consensus Grading for Cytokine Release Syndrome and Neurologic Toxicity Associated with Immune Effector Cells. Biol Blood Marrow Transplant 2019;25(4):625-38.

29. Wei J, Liu Y, Wang C, et al. The model of cytokine release syndrome in CAR T-cell treatment for B-cell non-Hodgkin lymphoma. Signal Transduct Target Ther 2020;5(1):134.

30. Sterner RM, Sakemura R, Cox MJ, et al. GM-CSF inhibition reduces cytokine release syndrome and neuroinflammation but enhances CAR-T cell function in xenografts. Blood 2019;133(7):697-709.

31. Hao Z, Li R, Meng L, et al. Macrophage, the potential key mediator in CAR-T related CRS. Exp Hematol Oncol 2020;9:15. 
medRxiv preprint doi: https://doi.org/10.1101/2021.03.17.21253300; this version posted March 20, 2021. The copyright holder for this preprint (which was not certified by peer review) is the author/funder, who has granted medRxiv a license to display the preprint in perpetuity. It is made available under a CC-BY-NC-ND 4.0 International license.

\section{Physiological (TCR-like) regulated lentiviral vectors for the generation of improved} CAR-T cells

LVs-Strong Promoter

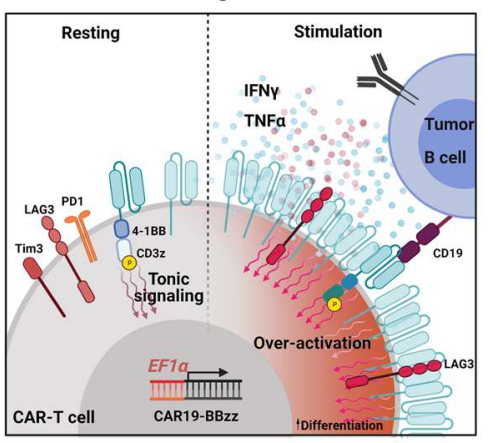

LVs-TCR-like Promoter

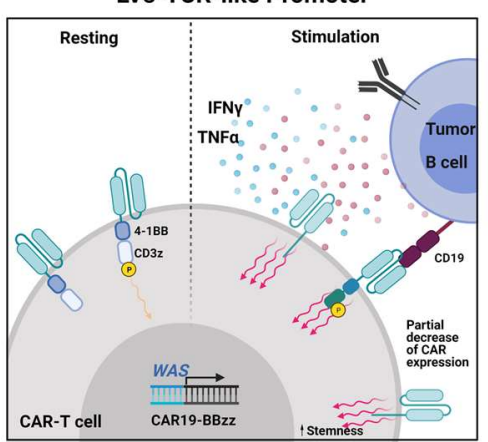

Authors

María Tristán-Manzano, Noelia Maldonado-Pérez, Pedro Justicia-Lirio, Pilar Muñoz, Marina Cortijo, Kristina Pavlovic, Rosario Jiménez-Moreno, Sonia Nogueras, MDolores Carmona Sabina Sánchez-Hernández, Araceli Aguilar-González, María Castella, Manel Juan, Concepción Marañón, Karim Benabdellah, Inmaculada Herrera and Francisco Martin.

\section{Correspondence}

f.martin@genyo.es

\section{In Brief}

Current CAR-T cells products use strong promoters to drive CAR expression which lead to high activation, tonic signalling and premature differentiation. Here, we propose the WAS promoter, which drives a partial decrease in CAR expression, as an alternative for the generation of TCR-like CAR-T cells in a LV context with improved characteristics. 
medRxiv preprint doi: https://doi.org/10.1101/2021.03.17.21253300; this version posted March 20, 2021. The copyright holder for this preprint (which was not certified by peer review) is the author/funder, who has granted medRxiv a license to display the preprint in perpetuity. It is made available under a CC-BY-NC-ND 4.0 International license.


$\mathbf{F}$

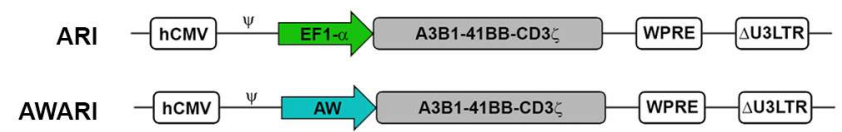

H

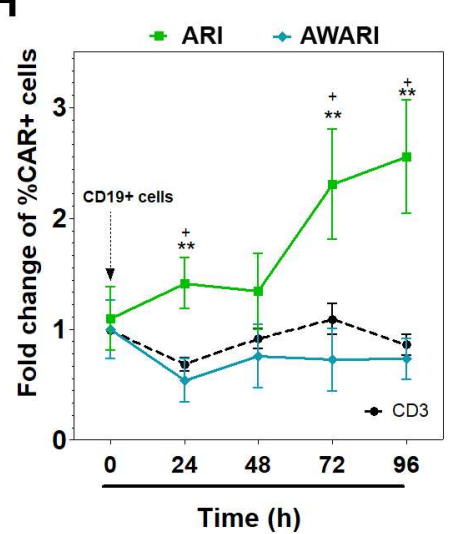

B
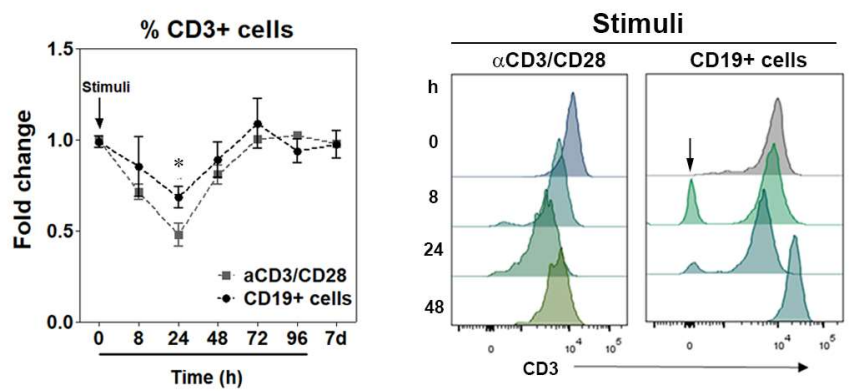

E
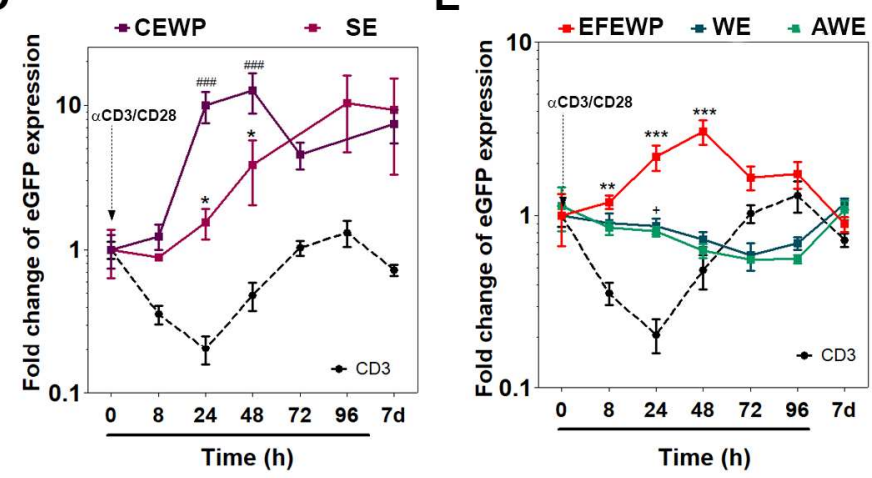

G

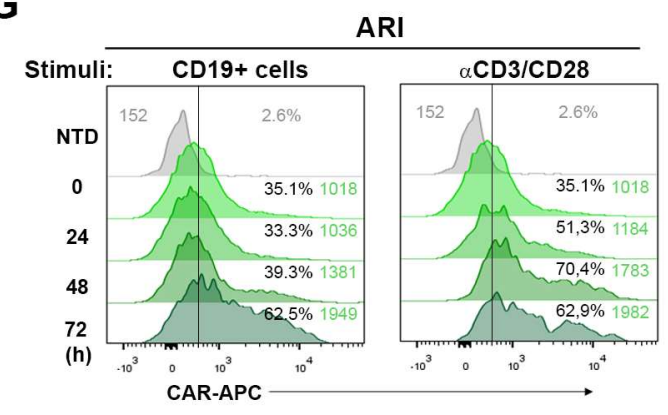

AWARI

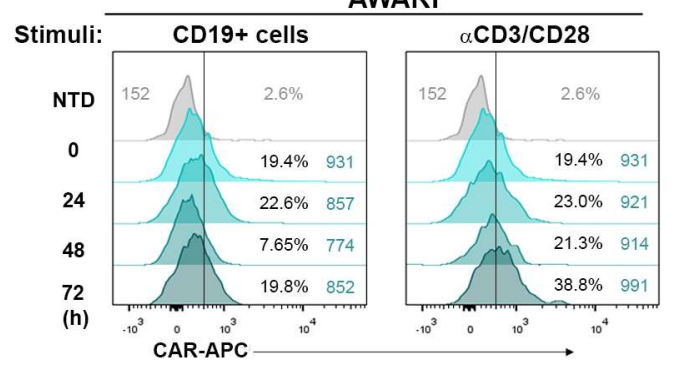


A

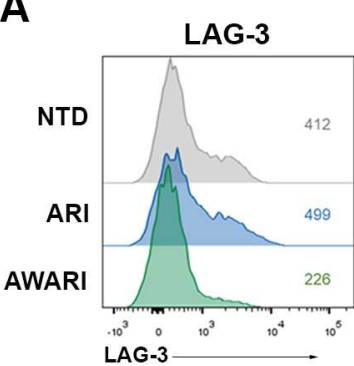
${ }^{10^{3}}$ LAG-3

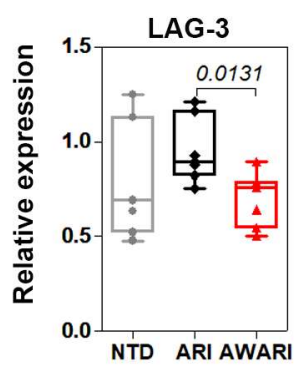

PD1

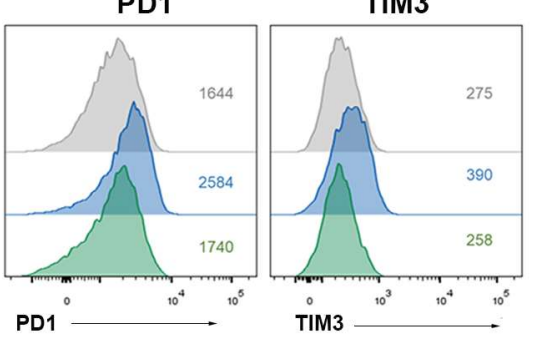

PD1

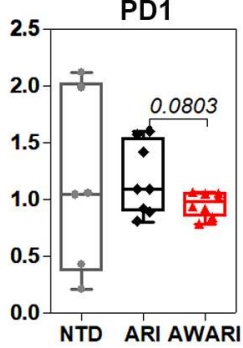

B

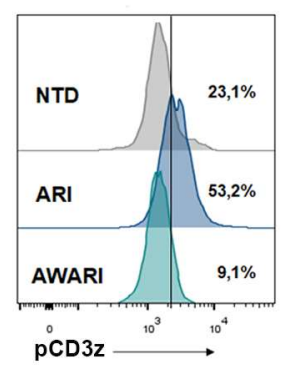

C

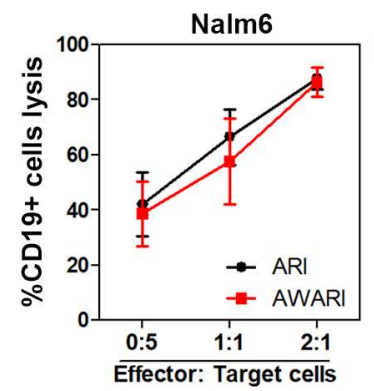

E

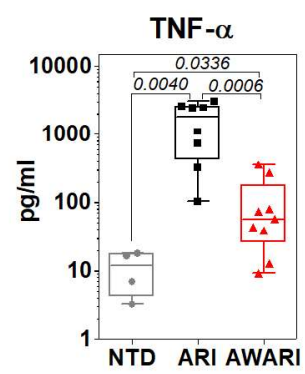

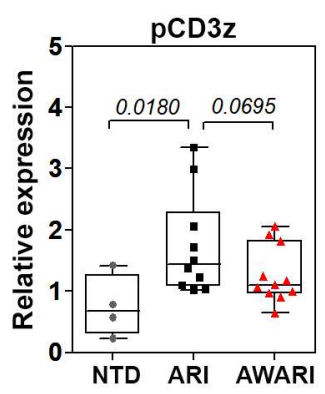

Namalwa

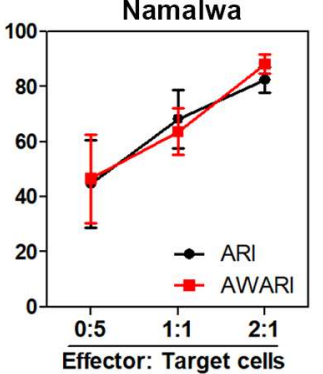

Effector: Target cells

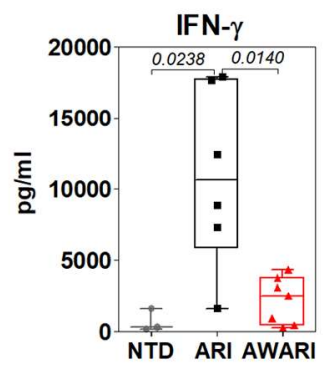




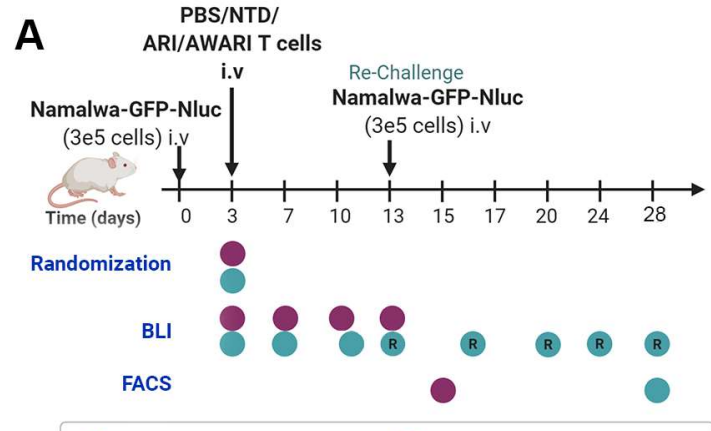

5 e6 $\mathrm{T}$ cells $(20-30 \%$ CAR+) $10 \mathrm{e} 6 \mathrm{~T}$ cells $(10-15 \%$ CAR+ $)$
B

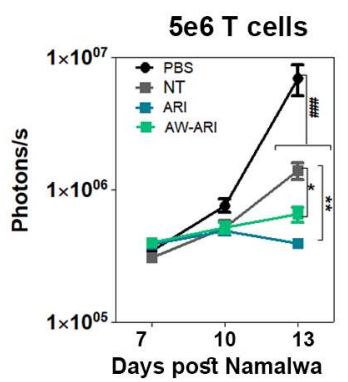

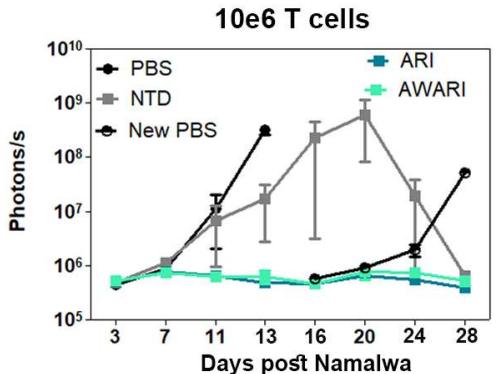

$10 \mathrm{e} 6 \mathrm{~T}$ cells

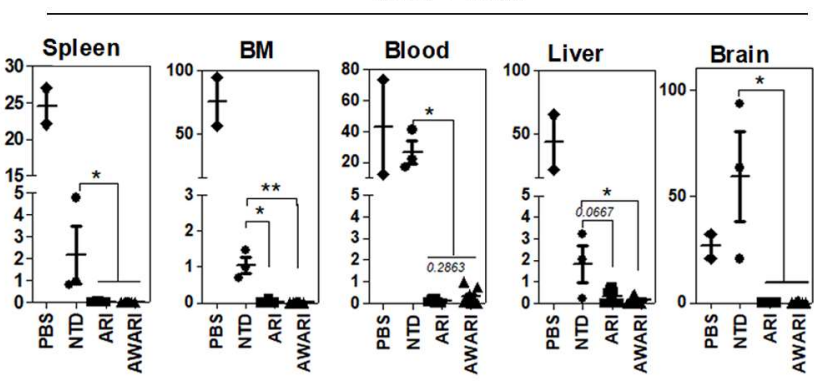

D

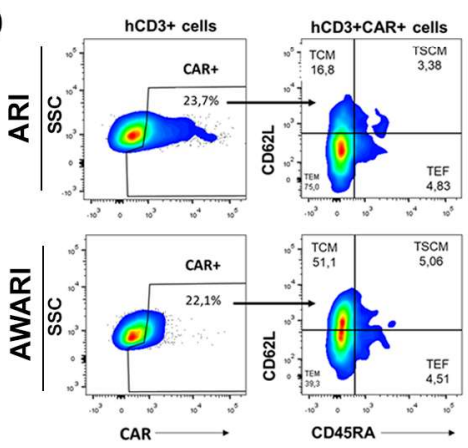

5 e6 T cells

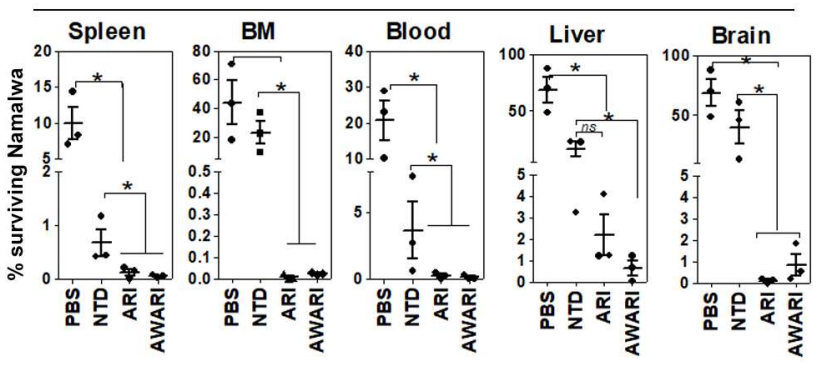

E

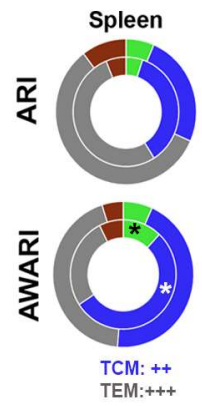

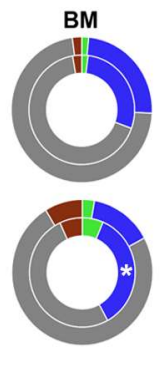
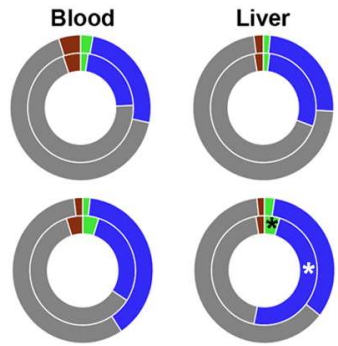

TCM:+++$$
\text { TEF }
$$

F

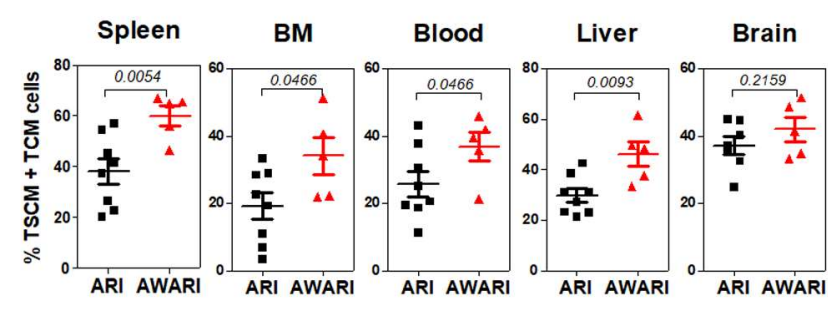

H

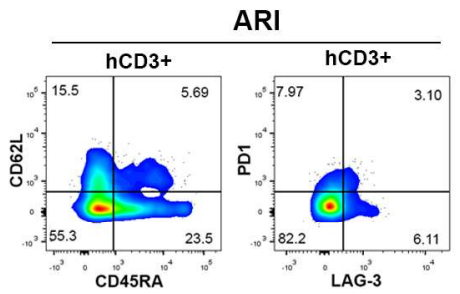

AWARI

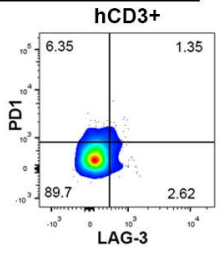

G

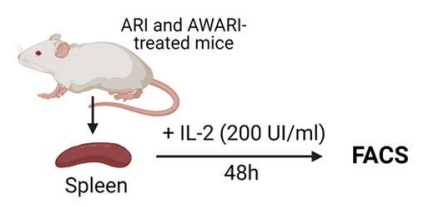

I

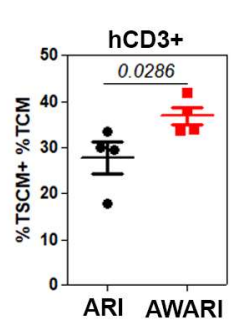


medRxiv preprint doi: https://doi.org/10.1101/2021.03.17.21253300; this version posted March 20, 2021. The copyright holder for this preprint (which was not certified by peer review) is the author/funder, who has granted medRxiv a license to display the preprint in perpetuity. It is made available under a CC-BY-NC-ND 4.0 International license.

A

CliniMACs

\#01 \#02

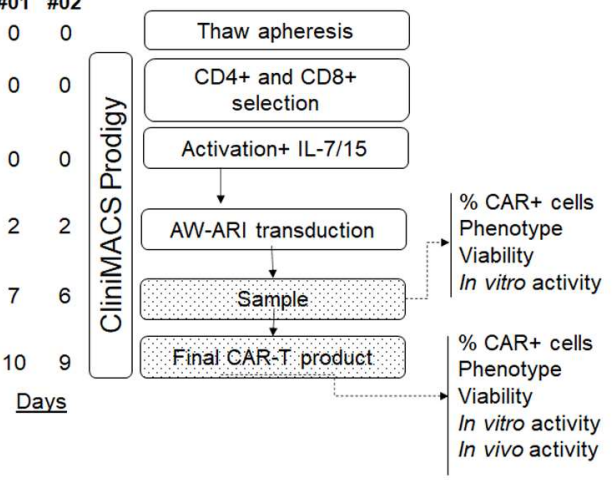

C

\begin{tabular}{lccccc}
\hline Parameter & Method & \multicolumn{2}{c}{ AWARI \#01 } & \multicolumn{2}{c}{ AWARI \#02 } \\
\hline Viability $(\%)$ & & Day 7 & Day 10 & Day 7 & Day 10 \\
Live CD3+ cells $\left(\times 10^{6}\right.$ cells) & FC & 94 & 98 & 96 & 98.7 \\
Live CD3+ cells $(\%)$ & FC & 1000 & 3352 & 674 & 3470 \\
CAR19+ cells $\left(\times 10^{8}\right.$ cells $)$ & FC/NC & 98 & 98 & 93.35 & 96.39 \\
CAR19+ cells $(\%)$ & FC & 152.8 & 534.98 & 151.31 & 691.92 \\
\end{tabular}

E

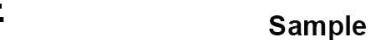

Sample

Final
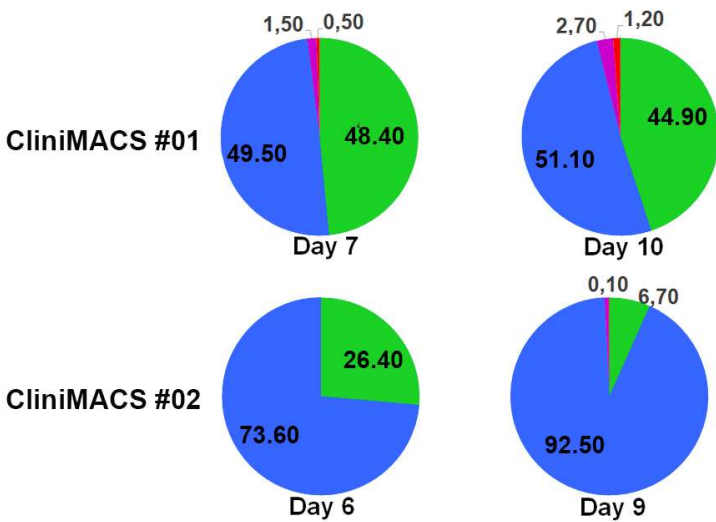

B

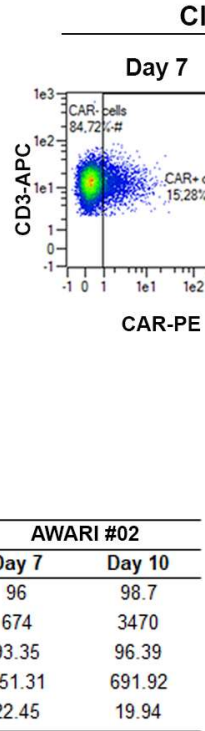

CliniMACS \#01
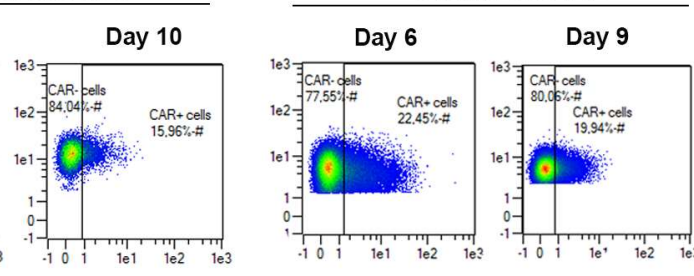

D

CD4

CD8

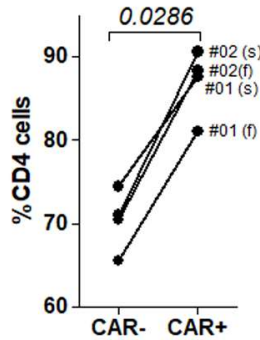

F

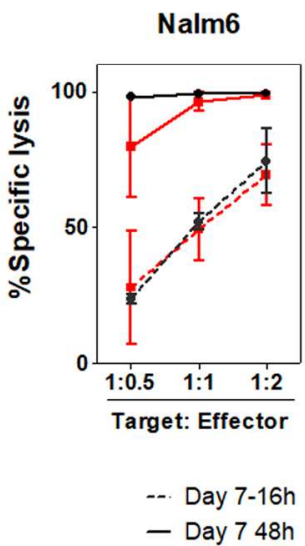

-CD45RA+ CCR7+ CD45RA- CCR7+ CD45RA+ CCR7-

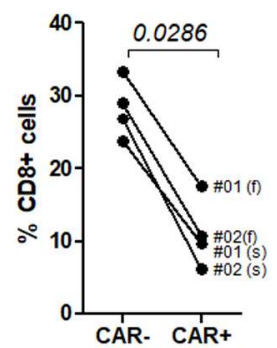

Namalwa

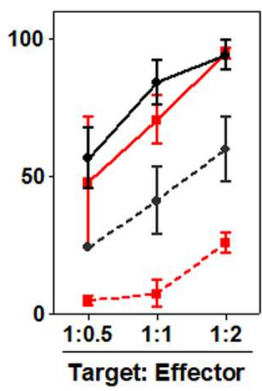

-. Day 10-16h

- Day $1048 \mathrm{~h}$ 
medRxiv preprint doi: https://doi.org/10.1101/2021.03.17.21253300; this version posted March 20, 2021. The copyright holder for this preprint (which was not certified by peer review) is the author/funder, who has granted medRxiv a license to display the preprint in perpetuity. It is made available under a CC-BY-NC-ND 4.0 International license.

A

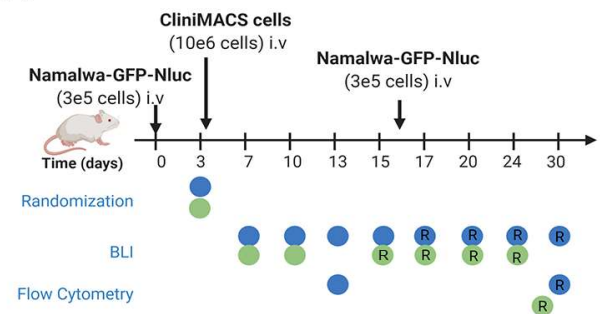

C

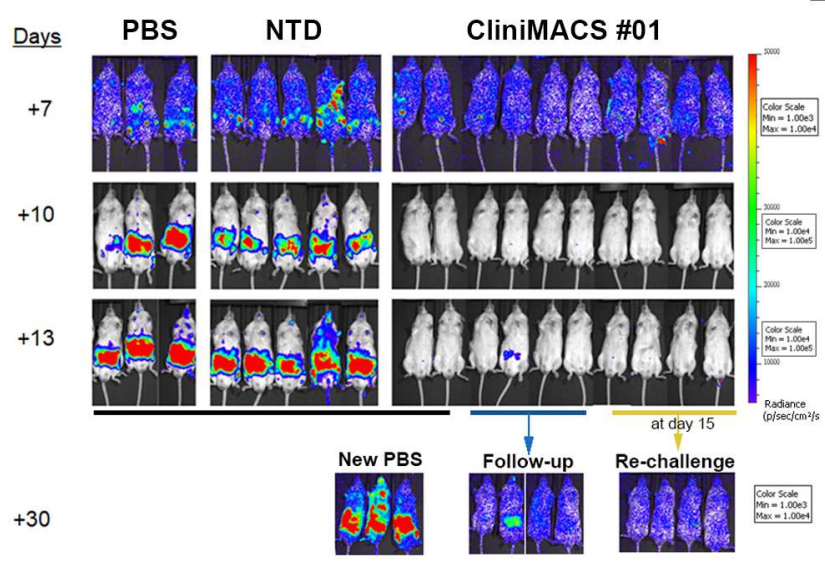

$\mathbf{E}$

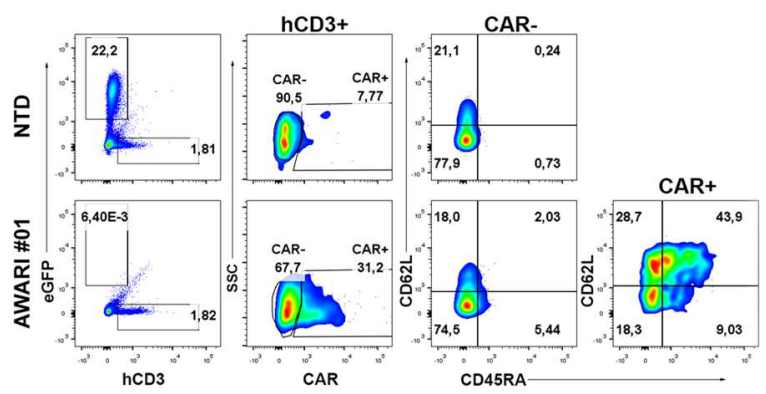

B

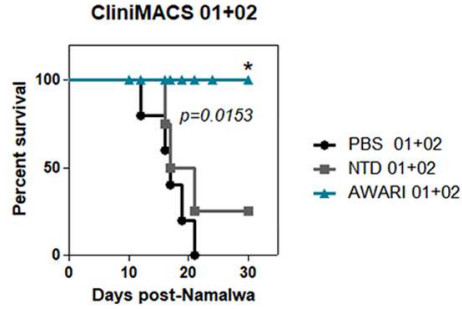

D

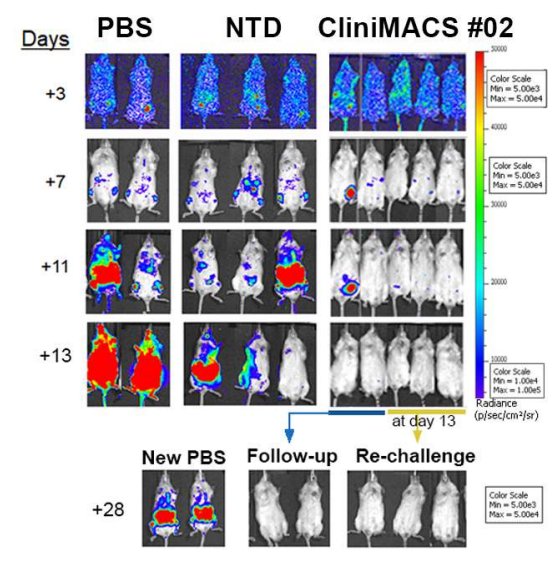

F
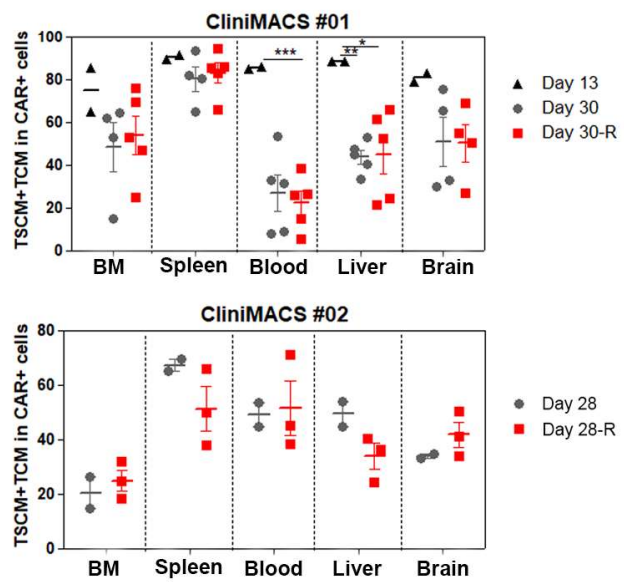
medRxiv preprint doi: https://doi.org/10.1101/2021.03.17.21253300; this version posted March 20, 2021. The copyright holder for this preprint (which was not certified by peer review) is the author/funder, who has granted medRxiv a license to display the preprint in perpetuity.

It is made available under a CC-BY-NC-ND 4.0 International license .

3 Figure 1. T cells transduced with WAS promoter-driven LVs mimic the TCR expression

4 pattern. A) Top: Timeline of the experiments to study eGFP expression pattern after TCR/CAR

5 stimulation. Bottom: diagrams of the different used eGFP-expressing LVs analyzed. B) Fold change

6 of CD3 expression (\% relative to $0 \mathrm{~h}$ ) in WT T cells stimulated with $\alpha \mathrm{CD} 3 / \alpha \mathrm{CD} 28$ and $\alpha \mathrm{CD} 19 \mathrm{CAR}-$

7 T cells stimulated with CD19+ cells. Left: fold change in CD3 expression at different times post-

8 stimulation. (Data are MeFI $\pm \mathrm{SEM} *$, indicates $\mathrm{p}<0,05,2$-way-ANOVA, Bonferroni post-Test. $\mathrm{n} \geq 5$ ).

9 Right: Representative histograms showing CD3 expression on WT T cells (left) and $\alpha$ CD19CAR-T

10 cells (right) at different times post-stimulation. C) Representative histograms of eGFP expression

11 driven by strong-promoter driven (CEWP, SE and EFEWP- top panels) and WAS-promoter driven

12 (WE, AWE - bottom panels) LVs at different times post-stimulation. D, E) Graphs showing fold change in eGFP (colored lines) and CD3 (black lines) expression along time after $\alpha \mathrm{CD} 3 / \alpha \mathrm{CD} 28$ stimulation of $\mathrm{T}$ cells transduced with viral promoter-driven (CEWP, SEWP) (D) or eukaryoticpromoters driven (EFEWP, WE and AWE) LVs (E). Fold change is calculated by the following formula: ((MeFI of GFP+ population xh/ MeFI of non-transduced cells xh)/ MeFI of GFP+ population 0h/ MeFI of non-transduced cells 0h). 2-way-ANOVA, Bonferroni post-Test, compared with CD3 pattern: *, $\mathrm{p}<0.05 ; * *, \mathrm{p}<0.01 ; * * *, \mathrm{p}<0.001 .+++$ indicates $\mathrm{p}<0.001$ for SEWP compared to $\mathrm{CD} 3$ expression. $\mathrm{n}=5$. F) Diagrams of the EF1a promoter-driven (ARI) and WAS-promoter driven (AWARI) LVs expressing the ARI-0001 CAR ( $\alpha$ CD19 A3B1-41BB-CD3ל) G) Representative histograms of CAR expression levels on CAR-T cells generated with the ARI (top) or AWARI (bottom) LVs and measured at different time points after activation with CD19+ cells (left) or $\alpha \mathrm{CD} 3 / \alpha \mathrm{CD} 28$ (right). H, I) Graphs showing fold change in CAR expression on ARI-CAR-T (green lines) and AWARI-CAR-T (blue lines) cells at different time points after activation with CD19+ cells $(\mathrm{H})$ or $\alpha \mathrm{CD} 3 / \alpha \mathrm{CD} 28$ (I). Data shows the percentage of CAR+ cells at different time points relative to 0 hours. Man-Whitney test, two tails, ** indicates $\mathrm{p}<0.01$ compared to CD3 and + indicates $\mathrm{p}<0,05$ compared to AWARI-CAR-T cells. $\mathrm{n} \geq 5$. 
medRxiv preprint doi: https://doi.org/10.1101/2021.03.17.21253300; this version posted March 20, 2021. The copyright holder for this preprint (which was not certified by peer review) is the author/funder, who has granted medRxiv a license to display the preprint in perpetuity.

It is made available under a CC-BY-NC-ND 4.0 International license .

1 Figure 2. TCR-like expression improves CAR-T cells propertiesin vitro. A) Top:

2 Representative histograms of LAG-3, PD1 and Tim3 expression of NTD (non-transduced,

3 gray), ARI (blue) and AWARI (green) CAR-T cells determined 10 days after activation with

$4 \alpha \mathrm{CD} 3 / \mathrm{CD} 28$. Bottom: Graphs showing expression levels of LAG-3, PD1 and Tim3 of ARI

5 and AWARI CAR-T cells related to the expression in NTD cells. Data are MeFI \pm SEM.

6 One-tailed Man-Whitney test (4 independent-donors). B) Left: Representative histograms of

7 intracellular phospho-CD3z expression after 10 days post-initial activation of NTD (gray),

8 ARI (blue) and AWARI (green) CAR-T cells. Right: Graph showing pCD3z expression

9 levels of each CAR-T cells related to NTD cells. Represented data is the ratio of pCD3z

10 MeFI of ARI or AWARI CAR-T cells divided by the pCD3z MeFI of NTD cells. One-tailed

11 Man-Whitney test (4 independent-donors, $\mathrm{n} \geq 4$ ). C) Lysis of CD19+ cells (Nalm6 and

12 Namalwa) at different ratios of co-culture with ARI and AWARI-CAR-T cells during 48h.

13 Percentage of lysis is related to NTD-driven non-specific CD19+ lysis ( $\mathrm{n}=5$ ). D) Relative

14 expression levels of LAG-3 on ARI and AWARI CAR-T cells 48h after co-culture with

15 Nalm6 (left) or Namalwa (right) cells. Data represents LAG-3MeFI of ARI or AWARI

16 CAR-T cells divided by the LAG-3 MeFI of NTD cells. One-tailed Man-Whitney test ( $\mathrm{n} \geq 5$ ).

17 E) Levels of secreted TNF $\alpha$ (left) and IFN $\square$ (right) produced by NTD, ARI and AWARI

18 CAR-T cells after $24 \mathrm{~h}$ of stimulation with Namalwa at ratio 1:1 and determined by ELISA (4

19 independent-donors, $\mathrm{n} \geq 4$ ).

Figure 3. In vivo anti-tumor activity and phenotype of ARI and AWARI CAR-T cells.

A) Experimental design of in vivo antitumor activity and phenotypic studies of 5e6 (purple dots) and a 10e6 (blue dots) of ARI and AWARI CAR-T cells. Re-challenge with new Namalwa is indicated with an arrow at day 16 in the $10 \mathrm{e} 6$ dose. Phenotypic analysis was

25 performed after sacrifice at day 13 for $5 \mathrm{e} 6$ dose and day 28 for $10 \mathrm{e} 6$ dose. B) Tumor 26 bioluminescence (BLI) progression with 5e6 (left) and 10e6 T cells doses (right) at different

27 days post-Namalwa inoculation. C) Percentage of surviving Namalwa-GFP-Nluc cells in 
1 bone marrow (BM), spleen, blood, liver and blood determined by FACS after the sacrifice

2 with the low (left panels) and high (right panels) doses. This value is analyzed in "singlets

3 human cells" gate (see M\&M). Two-tailed Mann-Whitney test, *, p<0.05; **, p<0.01, and

4 ***, $\mathrm{p}<0.001 . \mathrm{N}($ mice) of low dose: PBS=3, NTD=3, ARI=3, AWARI=3; and high dose:

$5 \quad \mathrm{PBS}=2, \mathrm{NTD}=3, \mathrm{ARI}=8, \mathrm{AWARI}=5$. D) Representative dot-plots of CAR expression and

6 phenotype of CAR+ cells of gated hCD3 from the spleen of ARI and AWARI mice after

7 sacrifice of the high-dose experiment. E) Graphical representation of proportions of $T_{N} / T_{S C M}$

8 (CD62L+CD45RA+) (green), $\mathrm{T}_{\mathrm{CM}}(\mathrm{CD} 62 \mathrm{~L}+\mathrm{CD} 45 \mathrm{RA}-)$ (blue), $\mathrm{T}_{\mathrm{EM}}$ (CD62L-CD45RA-)

9 (grey) and $\mathrm{T}_{\mathrm{EF}}(\mathrm{CD} 62 \mathrm{~L}-\mathrm{CD} 45 \mathrm{RA}+$ ) (red) subpopulations in ARI (top) and AWARI (bottom)

10 CAR+ cells in the indicated organs after sacrifice of challenged (outer circle) and re-

11 challenged (inner circle) mice. *, $\mathrm{p}<0.05$ when compared the $\mathrm{T}$ cells subsets of re-challenged

12 ARI and AWARI treated mice. Mann-Whitney one-tail. ++ and +++ $\mathrm{p}<0.01$ and $\mathrm{p}<0.001$

13 respectively of 2-way ANOVA, Bonferroni post-Test of all the population of the total mice

$14($ ARI $=8(3+5 R)$, AWARI $=5(2+3 R) . F)$ Percentage of $T_{N} / T_{S C M}$ and $T_{C M}$ after sacrifice of ARI and AWARI hCD3+CAR+ cells (ARI=8, AWARI=5, Mann-Whitney one-tail. G) Spleen

16 from treated mice were isolated and cells suspensions were cultured with $200 \mathrm{UI} / \mathrm{ml}$ of IL-2

17 in TexMACS medium and $2 \% \mathrm{P} / \mathrm{S}$ during $48 \mathrm{~h} . \mathrm{H})$ Representative dot-plots of

18 CD45RA/CD62L and PD1/LAG3 populations of ARI and AWARI mice. I) Percentage of

$19 \mathrm{hCD} 3+\mathrm{T}_{\mathrm{N}} / \mathrm{T}_{\mathrm{SCM}}$ and $\mathrm{T}_{\mathrm{CM}}$ after $48 \mathrm{~h}$ of in-vitro culture. Two-tailed Mann-Whitney test $(\mathrm{N}=4)$.

20 J) Percentage of PD1+LAG3+ cells. One-tailed Mann-Whitney test (N=4).

Figure 4. GMP-like large-scale production of AWARI CAR T cells. A) Time-line of the

23 GMP-like batches \#01 and \#02 of AWARI CAR-T cells in the CliniMACS Prodigy. B) Dot-

24 plots of CAR expression at days of sample (7/6) and final product (10/9) for both \#01 (left) and

$25 \# 02$ (right) batches. C) Data from viability, number of CD3, efficiency of CAR-T cell

26 transduction and number of obtained CAR-T cells. $\mathrm{FC}=$ flow cytometry, $\mathrm{NC}=$ Neubauer

27 chamber counting. D) Variation of percentage of CD4 and CD8+ cells in CAR-and CAR+ cells 
medRxiv preprint doi: https://doi.org/10.1101/2021.03.17.21253300; this version posted March 20, 2021. The copyright holder for this preprint (which was not certified by peer review) is the author/funder, who has granted medRxiv a license to display the preprint in perpetuity.

It is made available under a CC-BY-NC-ND 4.0 International license .

1 at sample (s) and final products (f). Two-tailed Mann-Whitney test. E) Graphical representation

2 of the $\mathrm{T}$ cells populations at sample (days 6 or 7) and final products (day 9 or 10).

$3 \mathrm{~T}_{\mathrm{N}} / \mathrm{T}_{\mathrm{SCM}}=$ Naïve/stem cell memory $(\mathrm{CD} 45 \mathrm{RA}+\mathrm{CCR} 7+), \mathrm{T}_{\mathrm{CM}}=$ central memory $(\mathrm{CD} 45 \mathrm{RA}-$

$4 \mathrm{CCR} 7+), \quad \mathrm{T}_{\mathrm{EM}}=$ effector memory $(\mathrm{CD} 45 \mathrm{RA}-\mathrm{CCR} 7-)$ and $\mathrm{T}_{\mathrm{EMRA}}=$ effector memory

5 RA+(CD45RA+CCR7-). F) In vitro specific lysis of CD19+ cells Nalm6 (left) and Namalwa

6 (right) CD19+ cells by AWARI CAR-T cells harvested at sample day (black line) and final day

7 (red line) for productions \#01 and \#02. CAR-T cells products were co-cultured at different

8 ratios during $16 \mathrm{~h}$ (dashed line) or $48 \mathrm{~h}$ (continuous line).

11 Figure 5. In vivo anti-tumor activity and phenotype of CliniMACS-produced AWARI-

12 CAR-T cells after one or two Namalwa challenges. A) Experimental design and time-line of

13 the two experiments with CliniMACS batches \#01 and \#02. $\mathrm{R}$ indicates re-challenge. B)

14 Survival of PBS, NTD or AWARI-inoculated mice of \#01 and \#02 products. Log-Ranked test.

15 C, D) Representative BLI images of tumor burden measured in \#01 (C) and \#02 (D)

16 experiments at different days post Namalwa inoculation as indicated. In both studies, at day 15

17 (\#01) or $13(\# 02)$ respectively, new Namalwa cells were inoculated to AWARI treated mice (re-

18 challenge, yellow line) and to control mice ('New PBS'). E) Representative dot-plots of

19 Namalwa/hCD3 presence, CAR+ cells of hCD3 and phenotype of CAR- and CAR+ of NTD

20 cells and AWARI CliniMACS \#01 from BM after sacrifice. F) Percentage of $\mathrm{T}_{\mathrm{N}} / \mathrm{SCM}+\mathrm{T}_{\mathrm{CM}}$

21 population in hCD3+CAR+ cells analyzed in different organs from mice with one or two

22 (rechallenge, R) inoculations of Namalwa tumor cells in \#01 (left) and \#02 (right) CliniMACS

23 batches at final day. Only when CAR+ population was $>1 \%$, data was analyzed and included

24 here. $\mathrm{N}$ (CliniMACS \#01): PBS=3, NTD=5, AWARI=10 (2 sacrificed at day 13, 4 mice with

25 one- and 4 mice with two-challenges. $\mathrm{N}$ (CliniMACS \#02): PBS=2, NTD=3, AWARI =5 (2+3

26 re-challenged mice). 2-way-ANOVA, Bonferroni Post Test, *, indicates $\mathrm{p}<0.05$, **, $\mathrm{p}<0.001$,

$27 \quad * * *, \mathrm{p}<0.0001$. 
medRxiv preprint doi: https://doi.org/10.1101/2021.03.17.21253300; this version posted March 20, 2021. The copyright holder for this preprint (which was not certified by peer review) is the author/funder, who has granted medRxiv a license to display the preprint in perpetuity. It is made available under a CC-BY-NC-ND 4.0 International license .

1 